\title{
The Effect Of Pow-Tega As Interactive Technique To Improve Students' Speaking Ability At Senior High School Student
}

\author{
Netty Huzniati Andas ${ }^{1}$, Burhanuddin Arafah ${ }^{2}$, Nur Ihsan $\mathrm{Hl}^{3}$, Kaharuddin ${ }^{4}$, Rohima Nur \\ Azizah Alhakim ${ }^{5}$ Roslina $^{6}$, Kartini Malik ${ }^{7}$ \\ 1,3,5,6,7 Department of English Language, Universitas Sembilanbelas November Kolaka, South East Sulawesi \\ 93561, Indonesia; E-mail Address: netty.andas31@gmail.com \\ ${ }^{2}$ English Department, Faculty of Cultural Sciences, Hasanuddin University of Indonesia; E-mail Address: \\ burhan-arafah@unhas.ac.id \\ ${ }^{4}$ Faculty of Education and Teacher Training, Universitas Islam Negeri Alauddin, Makassar, Indonesia; E-mail \\ Address: andi.kaharuddin@uin-alauddin.ac.id
}

Article History: Received:11 January 2021; Accepted: 27 February 2021; Published online: 5 April 2021

\begin{abstract}
Speaking is the art of conveying ideas and feelings by generating and sharing meaning through oral contact. Pow-Tega is a speaking skill teaching technique that combines a power teaching technique with a game to allow students to practice their speaking skills. Students' focus and excitement in speaking are developed using the power teaching technique. Students were inspired to study while playing the game because the classroom environment was more colorful. Researchers used a quantitative method by assigning preexperimental studies with one group pre-test and post-test to determine the impact of the Pow-Tega technique on students' speaking performance. This study included 33 students as participants. The researchers used a spoken test and video recording to gather data. Before beginning treatment, researchers gave all of the samples a pre-test, then began treatment by using the Pow-Tega Technique for six meetings, and eventually, researchers gave all of the samples a post-test. The results revealed that the mean post-test score $(3,93)$ was higher than the pre-test score $(3,39)$. Furthermore, at the significant stage of 0,05 and degree of freedom -19 , the $t_{\text {test }}(6,75)$ was higher than the $t_{\text {table }}(2.093) . \mathrm{H}_{0}$ has been refused, while $\mathrm{H}_{1}$ has been accepted. That means there was a significant effect of students' speaking ability after they were taught by using Pow-Tega.
\end{abstract}

Keywords: Motivation, Power Teaching and Game (Pow-Tega), speaking ability.

\section{INTRODUCTION}

As an international language, English plays an important role as a lingua franca used among many countries. People of the countries widely use English in almost all sectors of their lives among other things; commerce, technology, medic, business, research, education, and so on (Rao 2019; Arafah, B. \& Hasyim, M. 2019). In technology field, almost all software developments today in terms of communication devices, internet, as well as websites use English as well (Kaharuddin, Ahmad, D, Mardiana, Rusni, 2020). While in education sector, most research reports, scientific books and articles are written in English. Consequently, many people are motivated to learn English all over the world either as a foreign language or as a second language (Andi, K., \& Arafah, B. 2017). It is highly demanded that the people must have good command in English skills such as speaking, listening, reading, and writing skills. The fact shows that among the four skills, speaking is the most dominant skill to be learned by the people (Arafah, B., Thayyib, M., Kaharuddin, \& Sahib, H. 2020). They believe that mastering speaking skill will enable them to interact actively in their social life within this globalized world (Arafah, B., \& Kaharuddin, 2019).

In a nutshell, the mastery of speaking skill not only makes the learners able to convey meanings, to express ideas, to utter some opinions, even to address questions, but also facilitate them to establishes social relationships among them (Ismail,. Sunubi, A. H., Halidin, A., \& Amzah., Nanning., Kaharuddin. 2020). In this regard, speaking is generally viewed as a process of building social relationships, and sharing meanings (Derakhshan, Khalili, and Beheshti 2016; Kaharuddin, K., \& Rahmadana, A. 2020). In addition, Arafah, B. \& Kaharuddin (2019) assert that speaking skill is a crucial part of second or foreign language learning which leads it's the learners to the ability of interacting socially and effectively (Hasyim, M., Nursidah, \& Hasjim, M. 2019). The ability to interact socially and effectively means is that people use a language to communicate their ideas into words, talking about perceptions and feelings in their social life that they want other people to understand them (Arafah, K., Arafah, A. N. B., \& Arafah, B. 2020).

Based on the regulation of Ministry of Education and culture number 81A 2013. The classroom program for 2013 is Curriculum 2013. The aim of speaking in this program is to train students to communicate meaning in transactional and interpersonal language in a real-world environment. They should also be able to 
convey the essence of a brief practical text and a monologue in a variety of texts, such as recounts, informative, and narratives, in both formal and informal ways (Arafah, A. N. B., \& Setiyawati, D. 2020).

Teaching speaking is an essential aspect of acquiring a second language. The ability to speak effectively and easily in a second language leads to a learner's progress in academic achievement as well as later success in other aspects of life (Tavil 2010). As a result, it is critical that language teachers focus on teaching how to communicate rather than solely memorization, in order to provide a rich atmosphere where effective communication can take place (Bergil 2016). In addition, (Souriyavongsa et al. 2013) said teaching and learning would be effective if certain conditions are in place, such as the method of teaching English, the competence of the teaching method, engaging media, and the state of the environment. The world demands that the aim of teaching speaking should be to develop students' communicative skill so that they can articulate themselves and learn how to master the English language. As a result, students can learn the elements of speaking, such as fluency, accuracy, and comprehensibility, in order to communicate effectively (Masuram and Sripada 2020).

Speaking English fluently and accurately, on the other hand, is difficult because it requires extensive training and the use of suitable procedures, media, or equipment to improve one's speaking skills. In order to address the difficulties that students can face when learning to talk, more work from teachers is needed (Idrissova, Smagulova, and Tussupbekova 2015). In line with that, Yumru 2015 also discovered that there are eight variables in speech that can make it impossible for EFL learners to generate successful English in oral communication. Clustering, duplication, reduced styles, output variables, colloquial language, pace of execution, tension, rhythm, and intonation, and engagement are the ones to remember.

Before undertaking research in the second grade of SMAN 1 Kendari, the researcher talked with students and the English teacher at the school about their issues concerning speech difficulties. The researcher discovered that students struggle with English word pronunciation because the way English words are written differs from how they are sounded. According to the students, they are not fluent in English and have never spoken it before. Second, students fail to remember English phrases. Since, English words difficult to pronounce, they are also unfamiliar with the language. The third issue is a lack of learning resources, since most teachers are also untrained in using technology and applying it to English learning. Furthermore, the researcher obtains further information from the English teacher who confirmed that the students seem to have poor speech skills. Because of their circumstances, nearly all of the students come from the village, and we all know that studying English in the village is also minimal in terms of facilities and infrastructure. As a result, students have trouble in learning English especially in speaking skill.

Some students 'issues in speaking can be solved by providing an interesting strategy that make students interested in learning (Parupalli 2019). Wahyuni (2018) described that the use of appropriate strategy in teaching speaking will create a conducive classroom atmosphere, students will speak freely without feeling afraid of making mistake, and the students will enjoy the process of teaching hence the learning goals can be achieved. One of the strategy in teaching speaking is POW - TEGA, it is developed by Biffle (2008) and today is widely used by scholars, teachers, or lectures in teaching. POW-TEGA is a simple technique which combines the Power teaching strategy and Game in teaching. Power Teaching strategy is aimed to improve students' response and it also engage students to be more active in classroom (Andreani and Ying 2019), while according to (Dayanindhi and Hegde 2018) the using of game in teaching speaking can decrease student' tension to speak since the class full of fun and joys. Therefore, the games can make students relax, help them learn and express ideas more easily and games can also interest the students and keep them involving in a competition. In addition, games can be applied to help students learn better because the way they received the information is through an enjoyable learning process (Farias, Valério, and Mesquita 2018).

Some researchers have used POW-TEGA to develop students' speech competency in descriptive text. Armansyah (2019) confessed that POW-Tega is a technique that has a number of benefit for students especially in term of speaking skill, through POW-TEGA students are invited to speak confidently about their ideas, feeling, and thoughts. In another study, (Wahyuni 2018) showed that using the Power Teaching and Game in speaking classes improves students' incentive to talk because POW-TEGA provides a comfortable classroom atmosphere in which students can express their thoughts or knowledege. About the fact that both of the previous and current studies used POW TEGA to teach speaking, however, the current study's goal was somewhat different from the previous one. The distinctions were that this research was categorized as experimental research because the purpose of the study was to see whether there was a significant effect in the students' speak competency after they were treated with POW-TEGA, and in terms of the speaking aspect, the researcher used either fluency or accuracy to measure students' ability to speak.

\section{LITERATURE REVIEW} Speaking

According to Gudu (2015) speaking is one of the skills that students must acquire in order to learn English. ). It is important for students to understand the meaning first. Speaking is described in a variety of ways by various experts. The speakers use words to communicate with the listener not only to convey what is on their 
minds, but also to express what they need, such as knowledge, idea, etc. The majority of people may spend a significant portion of their daily lives interacting with others; thus, contact requires at least two people to talk in order to share knowledge, thoughts, beliefs, views, or feelings. Furthermore, Arafah, B., and Kaharuddin (2019) stated that speaking is the productive ability in the oral process of development, unlike the other skills; speech is more difficult because it involves the use of cognitive and psychomotor instruments. It requires more than just pronouncing the word; it must also express the lexical and semantic type based on linguistic consistency and comprehensibility. It is suggested that a great deal of preparation is required while speaking.

Naturally, students can exercise their speech skills on a regular basis in order to achieve their best results. Speaking is one of the language skills that has expanded on children's lives, and it starts with listening which means that speaking is a language capacity that evolves in youth, starting with the ability to listen. Speech and vocabulary have a bond, which a pupil requires by reading and listening exercises. To develop student speaking abilities, students should be allowed to use spoken language forms naturally and should be used regularly in their everyday lives (Gulec and Durmus 2015).

\section{Pow-Tega Strategy}

Pow-Tega strategy stands for Power teaching and game strategy. Pow-Tega is a teaching method of speaking that uses a mixture of power teaching and game techniques to increase students' focus (Armansyah 2019). Pow-Tega is a technique that mixes Power Teaching Technique and Games Technique. This approach aims to create a constructive environment in the speaking class. Power teaching is a teaching method that encourages students to speak up and be more innovative in the classroom. (Wahyuni 2018).

Biffle (2008) cited in (Armansyah 2019) provide several principles related the application of POWTEGA in a classroom. They are;

1. The class responds with a resounding "Yes." The first step in the Power teaching learning approach was to rely on the students' interest. The students responded "yeah" when the teachers said "school." The students said "yeah, yes" when the teachers said "class, class." Teachers can even say things like "classity, classity," to which students respond with "yessy, yessy," and so on. The teacher's tone and volume can also be used to evoke the students' attention. If the teacher says it in a loud voice, the students must answer in a loud voice, and vice versa.

2. Rules of the classroom. In light of the good application of this technique, the teacher should consider certain rules relevant to Pow-Tega. There are five rulers in total. They're; (1). Quickly follow the instructions (2). Raise your hand if you'd like to talk (3). Raise your hand if you want to get out of your seat (4). Make a wise decision (5). Maintain a positive attitude toward your beloved teacher.

3. Teach-Okay is the most effective learning activity in Whole Brain Teaching. After the instructor has given a one-minute explanation. Students will collaborate in groups of two to communicate their experience. When the teacher says "teach," the students answer with "okay" and go straight to their partner to teach each other, which can be repeated several times in order to get a successful outcome at the end of learning process.

4. The Scoreboard. Scoreboard is used to motivate the students after doing "teach-ok". In this theory, if the instructor does a good job, they will get a good emoticon. In the other hand, if they do poorly, they will get a poor emoticon.

5. Hands and Eyes. All mental activity is focused on seeing and hearing the teacher's lesson.

6. Look in the mirror. When the instructor says "teach" and the class reacts "Okay," the teacher will insert their own movements, songs, or chanting into this section of the lesson, and the students are encouraged to "mirror" the teacher.

7. Make a change. Both students must participate in the teaching and learning process. They would not teach the same student at the same time in this section. As a result, in order to include any student in the class, the teacher would instruct them to "Turn!" The students will respond "Switch!" and the group's teacher may rotate.

\section{Game Technique}

In using a power teaching technique and a game, the teacher will adjust the game to students' need. The researcher chooses talking stick game to encourage students learn how to communicate (Sung, Chang, and Liu 2016). The learning paradigm involves the use of a stick, with the person or students carrying the stick being expected to answer question from teacher until they had mastered the material. Students of kindergarten, junior high, and high school / vocational school will benefit immensely from playing the Talking Stick game. These exercises will not only allow students to practice communicating, but they will also create a comfortable atmosphere and inspire them to be an active participation (Wang and Tahir 2020). 


\section{METHODS}

The researcher used a pre-experimental of one group pretest and posttest design, in this study, the researcher only compared the effects of the pre-test and post-test design of one experimental class (Arafah, A. N. B., Arafah, A. D. B., \& Arafah, B. 2020). The population of this study was second grade students from SMA Negeri 1 Kolaka in the second semester. There were 370 students in the population. The participants in this study were from class XI IPA Galaksi, which has a total of 33 students. This class was taken by randomly selecting one of thirteen classes as a representative sample and ignoring the differences in student success between the classes. Purposive sampling was used to pick the samples. It implies that the researcher selected the sample based on the outcomes of a particular analysis. In this research, the samples were selected based on the English teacher's comment that her students' speaking ability in class XI IPA Galaksi was unsatisfactory. Therefore, It could be a valuable guide for researcher to design teaching material as well as provided a teaching technique. As a result, a teaching technician is needed. As a result, presenting Pow-Tega as a teaching method that can help them to improve their speaking ability is required. To assess students' speaking abilities, the researcher used an oral test in which students were asked to describe a topic (famous people, pets, favorite things) in front of the class. The researcher used three methods to gather evidence. The first was to perform a pre-test in the form of an oral speech. It was designed to assess students' abilities to communicate before beginning treatment. Second, the researcher taught speaking using the POW-Tega Technique. Six sessions were held to implement the treatments. The researcher used the Pow-Tega method in each meeting to help students achieve their speaking abilities in terms of fluency and accuracy. The treatment procedure was that the researcher centered the students by saying "class" or "teach," and the students replied "yeah" or "good." The researcher then demonstrated the class rule using power teaching principles. The students were then separated into groups. The number of students in each category was three or more. The material was explained by the researcher. The researcher then instructed the students to repeat the clarification or answer the questions by switching or turning the talking stick. Finally, make sure the students are speaking fluently and correctly. Lastly, the researcher administered students were asked to present the subject of speaking in an oral speech in the posttest. It was designed to assess the students' ability to communicate after they had been treated with the PowTega technique. The researcher used Statistical Package for the Social Sciences v20 to analyze the results (SPSSv20).

\section{RESULT AND DISCUSSION}

As mentioned previously, the objective of this research was to know whether or not there is a significant effect of applying Pow-Tega Strategy in students' speaking ability at the second grade of SMAN 1 Kolaka. Based on the result finding, the researcher found that there was a significant different of students' means score in Pretest and Postest. In pre-test, students pre-test was 3,39. After applying Pow-Tega in teaching speaking during six meetings the students' means score increased become 3.93. This was indicated that PowTega increased students' ability in speaking English. Further, from the result of interpretation showed that $t_{\text {table }}>$ $t_{\text {test }}(6,75>2,093)$, thus $\mathrm{H} 1$ was accepted and $\mathrm{H} 0$ was rejected. It was indicated that there were positive effect of using Pow-Tega technique toward students' speaking ability.

Pow-Tega became an interactive technique in teaching speaking due to Pow-Tega contain several crucial principle that can activate students' speaking performance. The first principle was the teacher's power in teaching speaking is based on previous experience as one step in the Pow-Tega process. This step could make the students enjoy and interesting to follow the teaching process. As stated by (Masino and Niño-Zarazúa 2016) the strategies of power teaching have improved student's response and it also engages the students to be more active made. In addition,(Wahyuni 2018) revealed that second language input should be highly collaborative and interactive process, in Pow-Tega technique students could understand the lesson easily because they got input in multiple ways that from teacher and from other students. Moreover, applying Pow-Tega technique in the classroom could create nice atmosphere. Through Pow-Tega technique, the students got more chance to express their ideas, they may asking for help to other friend, and also the relax situation in the classroom also make them freely to speak without any hesitation. It can be reduce students' anxiety and increase their selfconfidence (Rao 2019).

The students' motivation increased, which was the second factor. Since every student has the same opportunity to speak in front of the class, share their ideas, and discuss in their groups, students who are highly motivated in speaking activities can improve their speaking significantly. The students were also become more enthusiastic because they could talk, asked questions, and shared information actively during the group activity with the same chance (Hussain 2017). The characteristic of successful speaking class are the students talk as much as possible and participation is even where all students have fairly equal opportunity to contribute to the group as well as classroom discussion and students' motivation is high where the learners are eager to speak (Carolina and Astrid 2018).

.Based on the above description, applying the Pow-Tega technique had a positive effect on the students' 
speaking ability in terms of fluency and accuracy at SMA Negeri 1 Kolaka second grade students.

\section{CONCLUSION}

Speaking is an oral art that is more difficult than it seems at first and entails more than simply pronouncing sentences. More vocabularies practice is required for this speaking ability. The Pow-Tega technique was used to teach students how to exercise consistently in order to increase their enthusiasm and readiness to communicate. The use of correction as a means to help students learn to speak is important. Since completing the study and administering pre- and post-tests to the students using the Pow-Tega technique, the researcher discovered that $t_{\text {table }}>t_{\text {test }}(6,75>2,093)$ which means $\mathrm{H} 1$ was accepted and H0 was rejected. This was indicated that the Pow-Tega technique has a major impact on students' speaking ability at the second grade of SMAN 1 Kolaka academic year 2018-2019.

\section{REFERENCES}

1. Andi, K., \& Arafah, B. (2017). Using needs analysis to develop English teaching materials in initial speaking skills for Indonesian college students of English. The Turkish Online Journal of Design, Art and Communication (TOJDAC), Special Edition, 419-436.

2. Andreani, Wiwik, and Yi Ying. 2019. "'PowPow' Interactive Game in Supporting English Vocabulary Learning for Elementary Students." Procedia Computer Science 157:473-78. doi: 10.1016/j.procs.2019.09.005.

3. Arafah, B. \& Kaharuddin (2019). The Idol: A Model for Incorporating Literature in ELT. KnE Social Sciences, 43-59.

4. Arafah, B. \& Hasyim, M. (2019). Linguistic functions of emoji in social media communication. Opcion. Vol. 35 (24), 558-574.

5. Arafah, B., \& Kaharuddin, (2019). The Representation of Complaints in English and Indonesian Discourses. Opción, 35, 501-517.

6. Arafah, A. N. B., \& Setiyawati, D. (2020). Volunteerism in Sub-District Social Welfare Worker in Dosaraso Halfway House. International Journal of Psychosocial Rehabilitation, 24(Special Issue 1), 357-362. doi: 10.37200/ijpr/v24sp1/pr201165

7. Arafah, B., Thayyib, M., Kaharuddin, \& Sahib, H. (2020). An anthropological linguistic study on Maccera' Bulung ritual, Opción, 36, (27), 1592-1606

8. Arafah, K., Arafah, A. N. B., \& Arafah, B. (2020). Self-Concept and Self-Efficacy's Role in Achievement Motivation and Physics Learning Outcomes. Opción, 36, (27), 1607-1623

9. Arafah, A. N. B., Arafah, A. D. B., \& Arafah, B. (2020). Gene Therapy for The Treatment Of XLinked Retinitis Pigmentosa: A Review. European Journal of Molecular \& Clinical Medicine, 7(8), 1524-1532.

10. Armansyah. 2019. "Use Of Power Teaching Game Techhnique (Pow- Tega) To Improve Speaking Skill Of Junior High School Students." Borne Journal of English Language Education 1(2005):44-50.

11. Bergil, Ayfer Su. 2016. "The Influence of Willingness to Communicate on Overall Speaking Skills among EFL Learners." Procedia - Social and Behavioral Sciences 232(April):177-87. doi: 10.1016/j.sbspro.2016.10.043.

12. Carolina, Bocanegra Bonilla, and Ramirez Valencia Astrid. 2018. "Speaking Activities to Foster Students' Oral Performance at a Public School." English Language Teaching 11(8):65. doi: 10.5539/elt.v11n8p65.

13. Dayanindhi, Vijay Kautilya, and Shruti Prabhat Hegde. 2018. "Effectiveness of Microteaching as a Method of Developing Teaching Competence among In-Service Medical Teachers." Journal of Advances in Medical Education \& Professionalism 6(4):155-61.

14. Derakhshan, Ali, Atefeh Nadi Khalili, and Fatima Beheshti. 2016. "Developing EFL Learner's Speaking Ability, Accuracy and Fluency." English Language and Literature Studies 6(2):177. doi: 10.5539/ells.v6n2p177.

15. Farias, Cláudio, Carla Valério, and Isabel Mesquita. 2018. "Sport Education as a Curriculum Approach to Student Learning of Invasion Games: Effects on Game Performance and Game Involvement." Journal of Sports Science \& Medicine 17(1):56-65.

16. Gudu, Benter Oseno. 2015. "Teaching Speaking Skills in English Language Using Classroom Activities in Secondary School Level in Eldoret Municipality, Kenya." Journal of Education and Practice 6(35):55-63.

17. Gulec, Selma, and Nazli Durmus. 2015. "A Study Aiming to Develop Listening Skills of Elementary Second Grade Students." Procedia - Social and Behavioral Sciences 191:103-9. doi: 10.1016/j.sbspro.2015.04.487.

18. Hasyim, M., Nursidah, \& Hasjim, M. (2019). Online advertising: how the consumer goods speaks to 
women. Opción, 35(89), 826-845.

19. Hussain, Shafaat. 2017. "Teaching Speaking Skills in Communication Classroom." International Journal of Media, Journalism and Mass Communications 3(3). doi: 10.20431/2454-9479.0303003.

20. Idrissova, Mapruza, Batagoz Smagulova, and Madina Tussupbekova. 2015. "Improving Listening and Speaking Skills in Mixed Level Groups (on the Material of New English File)." Procedia - Social and Behavioral Sciences 199:276-84. doi: 10.1016/j.sbspro.2015.07.517.

21. Ismail,. Sunubi, A. H., Halidin, A., \& Amzah., Nanning., Kaharuddin. (2020). Paraphrasing Technique to Develop Skill for English Writing Among Indonesian College Students of English. Systematic Reviews in Pharmacy, 11(11), 291-297.

22. Kaharuddin, Ahmad, D, Mardiana, Rusni (2020) Contributions of Technology, Culture, And Attitude To English Learning Motivation During Covid -19 Outbreaks. Systematic Reviews in Pharmacy, 11 (11), 76-84. doi:10.31838/srp.2020.11.13

23. Kaharuddin, K., \& Rahmadana, A. (2020). Problem-Based Group Discussion: An Effective ELT Technique to Improve Vocational High School Students' Transactional Speaking Skills. Jurnal Ilmu Budaya, 8(2), 247-258.

24. Masino, Serena, and Miguel Niño-Zarazúa. 2016. "What Works to Improve the Quality of Student Learning in Developing Countries?" International Journal of Educational Development 48:53-65. doi: 10.1016/j.ijedudev.2015.11.012.

25. Masuram, Jyothi, and Pushpa Nagini Sripada. 2020. "Developing Speaking Skills through Task-Based Materials." Procedia Computer Science 172(2019):60-65. doi: 10.1016/j.procs.2020.05.009.

26. Parupalli, Srivinas. 2019. "The Importance of Speaking Skills in English Classrooms." Alford Council of International English \& Literature Journal(ACIELJ) 2(2):5-18.

27. Rao, Parupalli Srinivas. 2019. "The Importance of English in the Modern Era." Asian Journal of Multidimensional Research (AJMR) 8(1):7. doi: 10.5958/2278-4853.2019.00001.6.

28. Souriyavongsa, Thongma, Sam Rany, Mohamad Jafre Zainol Abidin, and Leong Lai Mei. 2013. "Factors Causes Students Low English Language Learning: A Case Study in the National University of Laos." International Journal of English Language Education 1(1):179-92. doi: 10.5296/ijele.v1i1.3100.

29. Sung, Yao Ting, Kuo En Chang, and Tzu Chien Liu. 2016. "The Effects of Integrating Mobile Devices with Teaching and Learning on Students' Learning Performance: A Meta-Analysis and Research Synthesis." Computers and Education 94:252-75. doi: 10.1016/j.compedu.2015.11.008.

30. Tavil, Zekiye Müge. 2010. "Integrating Listening and Speaking Skills to Facilitate English Language Learners' Communicative Competence." Procedia - Social and Behavioral Sciences 9:765-70. doi: 10.1016/j.sbspro.2010.12.231.

31. Wahyuni. 2018b. "The Power of Verbal and Nonverbal Communication in Learning." Pp. 80-83 in Proceedings of the 1st International Conference on Intellectuals' Global Responsibility (ICIGR 2017). Vol. 125. Paris, France: Atlantis Press.

32. Wang, Alf Inge, and Rabail Tahir. 2020. "The Effect of Using Kahoot! For Learning - A Literature Review." Computers and Education 149(January):103818. doi: 10.1016/j.compedu.2020.103818.

33. Yumru, Hulya. 2015. "EFL Teachers' Preferences for Teacher Learning Activities in a Professional Development Course." Procedia - Social and Behavioral Sciences 199:178-83. doi: 10.1016/j.sbspro.2015.07.503 